\title{
KANT AND THE EXPLANATORY ROLE OF EXPERIENCE
}

\author{
Anil Gomes \\ Trinity College, University of Oxford \\ Forthcoming, Kant-Studien [accepted 2011]
}

\begin{abstract}
We are able to think of empirical objects as capable of existing unperceived. What explains our grasp of this conception of objects? In this paper I examine the claim that experience explains our understanding of objects as capable of existing unperceived with reference to Kant's Critique of Pure Reason. I argue that standard accounts of experience's explanatory role are unsatisfactory, but that an alternative account can be extracted from the first Critique - one which relies on Kant's transcendental idealism.
\end{abstract}

\section{Objects}

We think of the world as containing particular things some of which are independent of ourselves... (P.F. Strawson, Individuals)

No one's been in the kitchen since he left it. On the table are his cup, Theo's empty mineral water bottle and, beside it, the remote control. It's still faintly surprising, this rigid fidelity of objects, sometimes reassuring, sometimes sinister. (Ian McEwan, $\underline{\text { Saturday) }}$

It is part of our everyday conception of ordinary objects that they are capable of existing unperceived: we think of the objects we leave behind as 
enduring in our absence. To think of objects in this way is to think of them as possessing various modal and temporal properties: even if there had been no-one around to observe it, the table would still exist and it will continue to exist should I leave the room. This conception of objects is built in to our concepts of ordinary everyday objects: to grasp the concept of a table is in part to understand that it is the kind of thing which can exist unperceived. What explains our grasp of this conception of objects?

An influential strand in the recent philosophy of perception literature has it that this understanding of ordinary objects is explained by our experience of the world: it is experience which explains our ability to think of objects in this way. ${ }^{1}$ John Campbell has termed this the explanatory role of experience: the principle that 'concepts of individual physical objects and concepts of the observable characteristics of such objects are made available by our experience of the world' (2002a, p.128). He elaborates this elsewhere as the claim that '[e]xperience of objects has to explain how it is that we can have the conception of objects as mind-independent' (2002b, p.121).

That there are ways of thinking about the world which are explained by experiences of a certain sort is a recognisable trope in the philosophy of mind. ${ }^{2}$ In his Anthropology Kant gives the example of our thinking about colours: 'To one who has never seen red among the seven colours, we can never make this sensation comprehensible' $(7: 168) .{ }^{3}$ Understanding what it is for something to be red requires one to have had colour experiences: it is colour experience which explains our grasp of colour concepts. The question raised by discussions of the explanatory role of experience is whether something analogous hold true of our ways of thinking of ordinary objects as capable of existing unperceived.

Let empirical concepts be the concepts of ordinary physical objects, concepts such as tree, table and chair. We deploy such concepts in making judgements about the world. And it is part of our everyday thinking about such objects that they continue to exist at times when we are not present. Call this the possibility of existence unperceived. This possibility is built

\footnotetext{
${ }^{1}$ See (McDowell 1986, p.243) on the claim that experience is revelatory; (Child 1994, pp.146-7); and, especially, (Campbell 2002a) and (2002b).

2 See, e.g., Campbell on colours (Campbell 2006); or McDowell and Evans on singular thought (McDowell 1986), (Evans 1982).

3 Anth: 'Dem, der unter den sieben Farben die rothe nie gesehen hätte, kann man diese Empfindung nie faßlich machen [...]'.
} 
into our empirical concepts: to grasp an empirical concept is to grasp the concept of something which can exist unobserved. Thus to accord experience an explanatory role is to make a claim about what it is that explains our understanding of objects as capable of enduring in this way. Call this claim (UE):

(UE): Experience explains our conception of objects as capable of existing unperceived.

What should we say about this claim? In some ways it can seem very Kantian. So phrased, (UE) has echoes of Kant's famous claim in the Critique of Pure Reason that thoughts without content are empty (A51/ B75), and in particular his claim that we can cognize an object 'only insofar as it is an object [Object] of sensible intuition' (Bxxvi). ${ }^{4}$ And - as the quote from the Anthropology attests - Kant was sensitive to the fact that certain forms of thought require a connection to experience. My aim in this paper is to explore the Kantian resonance of this claim with particular reference to the first Critique.

In assessing (UE) it is important to distinguish it from the distinct claim that experience explains our grasp of empirical concepts. Call this (EC) as follows:

(EC): Experience explains our grasp of empirical concepts.

One might think that these claims stand and fall together, for if empirical concepts have built into them the possibility of existence unperceived, then one cannot credit a subject with possession of an empirical concept without also crediting her with the conception of objects as capable of unperceived existence. Nevertheless, it does not follow that if experience explains our grasp of empirical concepts it must also explain our grasp of the conception of objects as capable of existing unperceived. We need to be mindful of the differences between these claims when deciding whether a Kantian defence of (UE) can be offered.

\footnotetext{
${ }^{4} \mathrm{KrV}:$ ' [...] sondern nur sofern es Objekt der sinnlichen Anschauung ist'. All references are in the standard ' $\mathrm{A}$ ' and 'B' notation, and refer to the Guyer and Wood translation (Kant 1998).
} 
As things stand, however, it is hard to know how to assess either of these purported explanatory roles. For it is simply not clear what it would be for experience to provide an explanation of the conception of objects as capable of existence unperceived. A natural way to understand this claim is as one concerning the acquisition of concepts: experience explains our grasp of this conception because we acquire it from experience. Call this the acquisition explanation. In the next section I will argue that we can find in Kant reason to reject (UE) when understood as a claim about the acquisition of concepts. So if (UE) is a claim about the acquisition of concepts, it finds no support in Kant's texts. In the final section I will suggest an alternative account of experience's explanatory role which draws on Kant's arguments in the first Critique. Whether or not this account will be amenable to contemporary philosophers of mind is a separate question. ${ }^{5}$

\section{Acquisition}

Let us begin with the acquisition explanation. According to this model of explanation, we explain our grasp of the conception of objects as capable of existence unperceived by showing how it is derived from experience. ${ }^{6}$ On the face of it, such a form of explanation seems committed to a brute empiricism about concept derivation. Nevertheless, showing how a concept is acquired does in general provide an explanation of our grasp of that concept. Take the concept of causality. Suppose one thought, with Kant, that the concept of causality 'obviously contains the concept of a necessity of connection with an effect' (B5), and that experience 'tells us... what is, but never that it must necessarily be thus and not otherwise' (A1). ${ }^{7}$ Then one might conclude that causality cannot be derived from experience, and thus that we do not possess the concept of causality, at least if understood as involving a necessary connection between cause and effect. $^{8}$ If one could show that causality could be derived from experience, perhaps by arguing that causation is often perceivable, and that if something is perceivable then one can derive its concept from experience,

5 There is also what one might term a deductive or justificatory explanation: one on which experience justifies our use of certain concepts. This mode of explanation can also be found in Kant, and although I will not discuss it here, much of what I say against the acquisition explanation applies equally to the deductive model.

${ }^{6}$ This form of explanation is suggested in some of Campbell's phrasing: he claims that what is at issue is how we can 'extract the conception of a mind-independent world' from experience (2002b, p.121).

${ }^{7} \mathrm{KrV}$ : 'ja in dem letzteren enthält selbst der Begriff einer Ursache so offenbar den Begriff einer Notwendigkeit der Verknüpfung mit einer Wirkung' (B5); 'Sie sagt uns zwar, was da sei, aber nicht, daß es notwendigerweise, so und nicht anders, sein müsse' (A1).

${ }^{8}$ Kant takes this to be Hume's reasoning: (B5). 
then that would go some way to explaining our grasp of the concept.' Locating experience as the source of a concept provides an explanation of our grasp of that concept by showing how it can be acquired.

To the extent that this line of thought is plausible it suggests that showing how we acquire a concept is, in general, a good way of explaining our grasp of that concept, regardless of whether the explanation proceeds by way of an acquisition from experience. Any account which shows how it is possible to acquire a concept will explain one's grasp of that concept, even if that account makes no reference to a derivation from experience. So if it were true that causality could not be derived from experience, that wouldn't preclude an alternative explanation being given of how one acquires the concept, say through some sort of abstraction from the functions of the mind. ${ }^{10}$ The explanatory force comes from showing how the concept is acquired, regardless of whether it is acquired from experience.

So the acquisition strategy is, in general I think, a good one: we can explain our grasp of a concept by showing how it is acquired. Thus if experience is to explain our grasp of a concept, we must show how that concept is acquired from experience. Kant sometimes calls this process an empirical deduction: one which shows 'how a concept is acquired through experience and reflection on it, and therefore concerns not the lawfulness but the fact from which the possession has arisen.' (A85/ B117). ${ }^{11}$ By showing how we acquire the concept from experience, we explain our grasp of the concept. And since to acquire a concept from experience is to derive it from experience, the explanatory role of experience is to be understood as a claim about the derivation of certain concepts.

A natural question to ask at this point is what it would be for a concept to be derived from experience, and the specifics of an answer will likely depend on one's views of the nature of concepts. Various accounts have been mooted, from mental representations, to skills and abilities to

\footnotetext{
${ }^{9}$ See (Anscombe 1981) for the claim that causality can be perceived.

${ }^{10}$ Kant claims that the categories - including causality - are not innate representations, but the product of an 'original acquisition', generated through reflection on the activities of the mind Discovery (8:221-23). So an acquisition explanation can still be given of the categories, just not one which involves acquisition from experience. See (Longuenesse 2005, p.28-9).

${ }^{11} \mathrm{KrV}:$ ' [...] welche die Art anzeigt, wie ein Begriff durch Erfahrung und Reflexion über dieselbe erworben worden, und daher nicht die Rechtmäßigkeit, sondern das Faktum betrifft, wodurch der Besitz entsprungen.'
} 
abstract contents. ${ }^{12}$ Nevertheless, it seems plausible that on whichever view of concepts we choose, we will still be able to make sense of the idea that experience could be the source of a concept - whether that involves acquiring a mental representation, a complex of skills and abilities or grasping an abstract content on the basis of experience. For my purpose here, I will assume that the acquisition claim can be made sensible on the various views of the nature of concepts.

Should we endorse either of the explanatory claims understood as claims about acquisition? Let's begin with (EC): experience explains our grasp of empirical concepts because we acquire our empirical concepts from experience. Kant would appear to endorse this claim. Empirical concepts, he says, are those which contain 'sensation': they 'presuppose the actual presence of the object' (A50/ B74), and 'can be drawn only from experience' (B3). ${ }^{13}$ This derivation takes place by means of comparison, reflection and abstraction from the manifold of intuition and 'the reality of these concepts rests on actual experience, from which, as to their content, they are drawn' Jäsche Logic (9:92). ${ }^{14}$ This 'drawing from experience' explains our grasp of empirical concepts, because 'we always have experience ready at hand to prove their objective reality' (A84/ B117). ${ }^{15}$

How is this claim defended? Kant appears to assume that our empirical concepts must be acquired from experience. In the Jäsche Logic he calls any concept which is not abstracted from experience a pure concept (9:92), and states that comparison, reflection and abstraction are the essential and universal conditions for any concept whatsoever (9:94 fn.1). ${ }^{16}$ It is by comparing my experiences of trees, reflecting on that which they have in common and abstracting from that which is presented that I come to acquire the empirical concept tree. ${ }^{17}$ And if all empirical concepts must be acquired from experience, then experience has to explain our grasp of such

\footnotetext{
${ }^{12}$ For an overview of the various options, see the entry on 'Concepts' in the Stanford Encyclopedia of Philosophy.

${ }^{13} \mathrm{KrV}$ : 'die die wirkliche Gegenwart des Gegenstandes voraussetzt' (A50/ B74); 'der nur aus der Erfahrung gezogen werden kann' (B3).

${ }^{14}$ Log: 'Die Realität dieser Begriffe beruht auf der wirklichen Erfahrung, woraus sie, ihrem Inhalte nach, geschöpft sind.' All references to the Logic lectures are to (Kant 1992).

${ }^{15} \mathrm{KrV}$ : '[...]weil wir jederzeit die Erfahrung bei der Hand haben, ihre objektive Realität zu beweisen.'

16 See also Vienna Logic (24: 905-906).

17 Jäsche Logic (9:94 fn.1), Vienna Logic (24: 907-908).
} 
concepts for there is no other method through which we can acquire them. ${ }^{18}$

But one might be sceptical of this claim. Consider testimony. It seems possible for me to acquire the concept of a koala without ever having experienced koalas, on the basis, perhaps, of conversations with an Australian friend. But acquiring a concept through testimony does not look like a case of acquisition from experience. Or consider theoretical concepts, such as electron. I do not need to see an electron in order to acquire the concept of an electron. So the acquisition of theoretical concepts does not seem to be a case of acquisition from experience. Both cases serve as counter-examples to Kant's claim that empirical concepts must be acquired from experience. ${ }^{19}$

One way to avoid this worry is to distinguish primary from secondary sources of acquisition and argue that acquiring a concept on the basis of testimony, say, is a secondary or derivative method of acquiring a concept. Secondary sources of acquisition are ones which would not be possible in the absence of a primary source of acquisition. In the case of testimony, one might think that acquisition of a concept through testimony would not be possible unless the testifier has acquired the concept through the primary method of acquiring it from experience. ${ }^{20}$ If this distinction can be made to bear weight, then it can still be true that we explain our grasp of empirical concepts by showing how we acquire them through experience, but in some cases that may involve showing how we acquired them on the basis of testimony from someone else who had acquired them from experience. $^{21}$

\footnotetext{
18 Béatrice Longuenesse argues that Kant's account of acquisition involves the synthesis of intuition and that such synthesis involves the use of certain categorial concepts. To the extent that this is right, Kant's endorsement of the acquisition version of (EC) is compatible with the involvement of a priori concepts in the acquisition process: experience still explains our grasp of empirical concepts because we can derive such concepts from experience, but that should not be taken to rule out the involvement of the categories in preparing the material for extraction. See (Longuenesse 1998).

19 (Cassam 2003, pp.97-98) stresses these points.

20 Or if she acquired it on the basis of testimony, that her testifier did not, and so on, on the grounds that there must have been some original acquisition of the concept from experience.

21 Cassam suggests that an account of how empirical concepts are derived might take testimony to be a case 'broadly speaking' of acquiring an empirical concept from experience (2003, pp.97-98). Marking a distinction between primary and secondary sources of acquisition allows us to acknowledge the dependence of testimonial acquisition on experience without enforcing a reduction of the former to the latter.
} 
That might do as a response to the case of testimony, but it is not clear how such a proposal applies to the case of theoretical concepts such as electron. And, regardless, some will claim further that it is possible to acquire an empirical concept without any experience at all: for there may be ways of acquiring concepts other than through experience. Bennett quotes Wittgenstein as saying that if someone underwent a brain operation which made him able to speak Latin fluently, we should not say that he had learned Latin at the operating table' (Bennett 1966: p.97). Learning through experience is only one way of acquiring concepts; a brain operation could serve equally well as a mode of acquisition. Unless Kant has an argument as to why such alternative methods of acquisition must be ruled out, then it seems false to conclude that our empirical concepts must be derived from experience.

Can Kant offer any response to this objection? The objection is good so long as Kant's claim is that we must derive our empirical concepts from experience. But it may be that a weaker claim will suffice for his purposes. For although the possibility of non-experiential acquisitions stands in opposition to the claim that we must acquire our empirical concepts from experience, it is compatible with the claim that all our empirical concepts can be acquired from experience - even if some of those concepts can also be acquired in non-experiential ways. Weakening the modal claim in this way avoids Bennett's Wittgensteinian objection whilst staying true to the tenor of Kant's remarks. And it leaves the burden of proof with the objector to show that there is an empirical concept which could not be acquired from experience.

However, once weakened in this way, Kant's account of the acquisition of empirical concepts can no longer serve as a defence of (EC), for (EC) has it that experience explains our grasp of empirical concepts because we do acquire such concepts from experience. The weakened Kantian claim has it that it is always possible for us to acquire our empirical concepts from experience. But - on the acquisition reading - this shows only that it is possible for experience to explain our grasp of empirical concepts. And that falls short of actually providing such an explanation. Although the acquisition form of (EC) is certainly a Kantian claim, its defence appears uncertain.

Let us turn now to (UE), the claim that experience explains our conception of objects as capable of existing unperceived. Under the 
acquisition reading, (UE) holds that experience explains our grasp of the conception of objects as existing unperceived because we acquire this conception of objects from experience. What should we say about this claim?

Given that the grasp of an empirical concept requires one to possess the conception of objects as capable of existing unperceived, one might initially think that any support for (EC) must transfer over to (UE). If empirical concepts can be acquired from experience, and if the conception of objects as capable of unperceived existence is required in order to possess an empirical concept, then one might think that this conception must also be capable of being acquired from experience. But this move is unsound: one can think that we acquire empirical concepts from experience without any commitment to the necessity of acquiring everything that is required to possess an empirical concept from experience.

Moreover, this move would be a mistake by Kant's lights. For there may be concepts which are presupposed in order for a subject to have any experience at all, and which therefore must be credited to any subject capable of grasping an empirical concept. But the very fact that these concepts are presupposed by experience tells against them being acquired from experience. So if there are any concepts the possession of which is a necessary condition on the possibility of experience, then we can see both why any subject who possesses empirical concepts must possess these presupposed concepts and also why we should not think of them as being acquired from experience. Kant's commitment to the acquisition form of (EC) - as unsteady as it was - need not involve any commitment to the corresponding version of (UE).

Nevertheless, even if (UE) does not follow from (EC), should we endorse it in its own right? At first blush it appears problematic that the conception of objects as capable of unperceived existence could be derived from experience. For grasping this conception of objects involves understanding the modal and temporal properties that objects possess: to think of objects in this way is to think of them as enduring in our absence, as continuing to exist if we leave the room. But it seems plausible that in order for a concept to be derived from experience, the feature in question must be present in experience. And - one might hold - those modal properties which make up our conception of objects as capable of unperceived existence are not features of our experience. If deriving a concept from experience requires 
its referent to feature in experience, and if the modal properties which make up one's conception of objects as capable of existence unperceived do not feature in experience, then it looks like the conception of objects as capable of unperceived existence cannot be derived from experience. Call this the argument from non-presentation.

One might extract this argument from Kant by noting that modality is one of Kant's four groupings of categories and that - at least with regard to the modal category of necessity - experience tells us 'what is, but never that it must necessarily be thus and not otherwise' (A1). More generally, you might think, with A.W. Collins, that '[c]ollectively the Categories are concepts of an "object" in the sense in which an object is something that endures between transient experiences of it' (Collins 1999: p.57), and if the categories cannot be given in experience - as Kant sometimes appears to suggest $\mathrm{t}^{22}$ - then the concept of an object which can endure between transient experiences of it cannot be derived from experience. That would provide us with an argument against the claim that our conception of objects as capable of unperceived existence could be derived from experience. $^{23}$

However, this can't quite be right, even in Kant's own terms, because to the extent that there is any plausibility in Collins's claim that the categories collectively make up our conception of objects as capable of existing unperceived, it is the schematised versions of the categories, those that are connected through a schema, making 'application of the category to appearances possible' (A137/ B176). Without schemata 'the categories... do not represent any object' (A147/ B187): it is only once schematised that they are provided 'with a relation to objects, thus with significance' (A146/B185). ${ }^{24}$ Thus if the categories do collectively constitute our conception of objects as capable of unperceived existence, it must be in

22 E.g. Now pure concepts of the understanding, however, in comparison with empirical (indeed in general sensible) intuitions, are entirely unhomogenous, and can never be countered in any intuition [Nun sind aber reine Verstandesbegriffe, in Vergleichung mit empirischen (ja überbaupt sinnlichen) Anschaunngen, ganz ungleichartig, und können niemals in irgendeiner Anschauung angetroffen warden]' (A137/ B176) - though see n.28 and the comments in the main text below.

${ }^{23}$ C.D. Broad interprets Kant as providing an argument from non-presentation along these lines. (Broad 1978, pp.9-11).

${ }^{24} \mathrm{KrV}$ : 'die Anwendung der Kategorie auf Erscheinungen möglich' (A137/ B176); 'Also sind die Kategorien, ohne Schemate, nur Funktionen des Verstandes zu Begriffen, stellen aber keinen Gegenstand vor.' (A147/ B187); 'Also sind die Schemate der reinen Verstandesbegriffe die wahren und einzigen Bedingungen, diesen eine Beziehung auf Objekte, mithin Bedeutung zu verschaffen [...]' (A146/ B185). 
their schematised form - and the schematised forms of the categories do involve some presentation in experience. This is how they contrast with transcendental ideas, such as those of God and Soul. ${ }^{25}$ As Kant stresses in the Vienna Logic, the objects of the pure concepts of the understanding can be encountered in experience: 'This happens through examples. An example of causality is: fire destroys wood.' (24:906). ${ }^{26}$ If the object of a pure concept cannot be given in experience 'then it is a concept not of the understanding but of mere reason...' (24:906). ${ }^{27}$ So Kant's account of the categories does not lend any support to the claim that the capacity of objects to exist unperceived is not presented in experience. ${ }^{28}$

And regardless of Kant's own reasons, it is not clear that we should accept the non-presentation claim, for experience does seem to present us with material objects as objects capable of existing unperceived. When you open your eyes, for instance, it seems to be part of the character of your experience that the objects you see were already there: experience presents such object as having been in existence before you perceived them. Or consider, in this context, Mike Martin's example of someone staring at a blue cross on a white piece of paper, not knowing that there is in fact a densely packed ream of paper crosses before her, each imperceptibly dissolving into the other. ${ }^{29}$ As Martin points out, there is a temptation to think of this experience as involving an illusion of persistence: it seems to her as if the same blue cross continues to exist from one moment to the next. And one way to account for this temptation is to say that her experience incorrectly presents to her the appearance of a persisting object that endures through time. This provides some support for Kant's claim that the schematised categories have some purchase in experience.

Martin's example concerns the capacity of objects to endure, but we may be able to extend the example to support the wider claim that the capacity of objects to exist unperceived is presented in experience. Consider a Star Trek style holodeck which you know to replicate objects within your visual

\footnotetext{
25 See Prolegomena (4:329), Jäsche Logic (9:92).

${ }^{26} \mathrm{~V}$-Lo/Wiener: 'kann man den Gegenstand dieses seines Verstandes-Begriffes in der Erfahrung antreffen? Resp. Ja. Dieses geschieht durch/ die Beyspiele. Ein Beyspiel der causalitataet ist: das Feur zerstört das Holz.'

27 V-Lo/Wiener: 'Dann ist er ein Begriff nicht des Verstandes, sondern der bloßen Vernuft.'

28 The role of the passage at A137, quoted in n.22, is not then to deny that the categories can be presented in experience but rather to emphasise the heterogeneity of pure concepts and sensible intuition.

${ }^{29}$ (Martin 2002, pp.183-4)
} 
field to give the appearance of a particular scene. And let's assume that it does so by replicating such objects out of matter which is destroyed once the object moves out of your visual field. As you turn your head away and then back, the objects you were looking at are destroyed and new ones are created in their place. It appears to you as if there are certain objects in your environment, and this is correct, for those objects really are in front of you. But there is a sense in which it seems to you as if the objects you experience endure throughout your transient experiences of them, that they endure whilst your head is turned. One explanation for this is that experience presents those objects as capable of existing unperceived. This would give some support to the claim that, contrary to the argument from non-presentation, the capacity of objects to exist unperceived is given in experience.

The prospects, then, for the argument from non-presentation appear dim. But that need not matter, for we have already highlighted a more direct Kantian argument against the acquisition version of (UE), namely that the conception of objects as capable of unperceived existence is presupposed by experience and therefore cannot be so derived. Here the claim is that the concepts which make up our conception of objects as capable of existing unperceived, concepts such as modality and substance, are necessary conditions on the possibility of experience, and as such cannot be derived from experience. Call this the argument from presupposition. If the argument from presupposition is right, then we cannot derive our conception of objects as capable of unperceived existence from experience because that conception is a condition on the very possibility of experience.

How might this argument from presupposition proceed? One option would be to return to Collins's claim that the categories, collectively, constitute our conception of objects as capable of enduring through transient perceptions of them. If that is right, and if Kant has an argument to the effect that the categories are conditions on the possibility of experience, then the conception of objects as capable of existence unperceived will be presupposed by experience, and thus cannot be derived from it. So on this way of motivating a Kantian argument from presupposition, the question turns on whether the categories are conditions on the possibility of experience. If they are conditions on the possibility of experience, then they are presupposed by experience, and thus unable to be derived from it. 
How might one argue for this claim? Kant thinks that he needs to show that the categories are conditions on the possibility of experience in order to assure their objective validity (A96-97), and his argument for this thesis takes place within his transcendental deduction of the categories. That suggests that any evaluation of this argument from presupposition requires an assessment of the merits of the transcendental deduction, something which I do not propose to do here. ${ }^{30}$ Nevertheless, even without such an evaluation, the argument from presupposition demonstrates that the acquisition form of (UE) does not simply follow from any commitment to (EC) and, more importantly, that there are strong Kantian currents which tell against any such claim. Furthermore, to the extent that one finds it plausible that this conception of objects could be presupposed by experience - to the extent, that is, that one finds it plausible that we are required to possess this conception of objects in order for there to be anything approximating experience at all - then we have a reason to reject the acquisition reading of (UE). We do not acquire our conception of objects as capable of unperceived existence from experience. ${ }^{31}$

Let me summarise the discussion thus far. According to the acquisition strategy, we explain our grasp of a concept by showing how it can be acquired. On this model of explanation, (EC) and (UE) are to be understood as claims about the role experience plays in the acquisition of certain concepts. My contention is that although Kant shows some sympathy towards (EC), this doesn't extend towards the acquisition account of (UE). If (UE) is to be understood as a claim about the acquisition of concepts, then experience doesn't explain our understanding of objects as capable of existing unperceived.

\section{Possible Experience}

The acquisition defence of (UE) appears wanting, then. But are there other ways in which this claim might be defended? In the remaining part of this paper I want to investigate the options for an alternative account of experience's explanatory role. What we need is an explanation which

\footnotetext{
${ }^{30}$ I discuss the Transcendental Deduction in (Gomes 2011).

${ }^{31}$ Note that the presupposition claim may be accepted by those working outside a Kantian framework. Gareth Evans (Evans 1980) argues that a subject's conception of objects as capable of unperceived existence relies on an implicit knowledge of the propositions of a primitive mechanics; a body of knowledge which is presupposed by experience and therefore cannot be extracted from experience. The implication seems to be that because the primitive mechanics cannot be derived from sensory experience, neither can one's conception of objects as capable of existing unperceived.
} 
relates experience to our conception of objects as capable of existing unperceived, but does so without focusing on acquisition stories about the derivation of concepts. The particular mode of explanation I want to explore comes from consideration of Kant's account of empirical objects.

Kant's discussion of empirical objects has to be situated against the background of his self-affirmed empirical realism: 'every outer perception therefore immediately proves something real in space, or rather is itself the real; to that extent empirical realism is beyond doubt...' (A375). ${ }^{32}$ It is the objects of outer perception that are empirically real: they have 'a reality which need not be inferred, but is immediately perceived' (A371). ${ }^{33}$ But these objects of experience, empirically real as they are, are also appearances. What does Kant mean by this? Appearances are first defined as 'the undetermined object[s] of an empirical intuition' (A20/ B34), ${ }^{34}$ and Kant sometimes refers to them as the objects of representation. ${ }^{35}$ But there are many passages in which he takes appearances to be 'nothing but representations' (A250). ${ }^{36}$ In both formulations, empirical objects, as appearances, bear an important relation to our representations.

The exact account we give of this relation has significant implications for the ontological status of appearances, and thus of empirical objects. Opposing positions have been taken according to whether we should consider appearances as mental entities, dependent on the subject for their existence, or as real objects independent of us considered from a certain perspective. ${ }^{37}$ Nevertheless, without involving ourselves in that debate, I want to suggest that one important aspect of Kant's identification of appearances with representations is that it highlights the close connection Kant draws between an empirical object and our capacity for

\footnotetext{
${ }^{32} \mathrm{KrV}$ : 'Alle äußere Wahrnehmung also beweist unmittelbar etwas Wirkliches im Raume, oder ist vielmehr das Wirkliche selbst, und insofern ist also der empirische Realismus außer Zweifel [...]'

${ }^{33} \mathrm{KrV}$ : 'eine Wirklichkeit [...], die nicht geschlossen werden darf, sondern unmittelbar wahrgenommen wird.'

${ }^{34} \mathrm{KrV}$ : 'Der unbestimmte Gegenstand einer empirischen Anschauung heißt

Erscheinung.'

35 E.g., 'Appearances, as objects of perception [Erscheinungen, als Gegenstände der Wabrnehmung]...' (B207)

${ }^{36} \mathrm{KrV}$ : '[...] da Erscheinungen nichts als Vorstellungen sind [...]'. See also (A101), (A109), and especially (A365 ff.). For evidence that this identification continues into the second edition, see (A492/ B520) and (A494/ B522).

$37 \mathrm{On}$ the side of appearances as mental entities, see e.g. (Strawson, 1966), (Bennett, 1966). For the contrasting position see, e.g., (Allison, 1983), (Matthews, 1982).
} 
representation: empirical objects, as appearances, are tightly connected to our ability to represent them in experience.

Consider the following passage in which Kant identifies appearances and representations:

We have said above that appearances themselves are nothing but sensible representations, which must not be regarded in themselves, in the same way, as objects (outside the power of representation) (A104) ${ }^{38}$

At least one function of the parenthesised addendum is to emphasise the fact that empirical objects, as appearances, cannot be given to us independently of our capacity to represent them: as Kant continues, 'we have nothing that we could set over against this cognition as corresponding to it' (A104). ${ }^{39}$ In stressing the identification of appearances and representations, Kant is drawing attention to the fact that our access to empirical objects is dependent on our capacity for representation: for Kant, 'empirical representation constitutes our access to objects.' (Collins 1999: p. 34$).^{40}$

Why is this important? This focus on the relation of empirical objects to our capacity for representing them evinces a central part of Kant's thinking about empirical objects, namely that such objects bear a constitutive relation to the possibility of experiencing them. 'The objects of experience are never given in themselves', Kant says, 'but only in experience' (A492/ B521), ${ }^{41}$ such that something which could not be given to us in experience - something, that is, which was incapable of being represented - could not be an empirical object. For Kant it makes no sense to talk of empirical objects apart from the possibility of their being given to us in experience and it becomes something like a category mistake to apply the concept of an empirical object outside of experience: 'To call an appearance a real thing prior to perception means either that in the continuation of

\footnotetext{
${ }^{38} \mathrm{KrV}$ : 'Wir haben oben gesagt: daß Erscheinungen selbst nichts als sinnliche Vorstellungen sind, die an sich, in eben derselben Art, nicht als Gegenstände (außer der Vorstellungskraft) müssen angesehen warden.' 'Außer' - translated here as 'outside' need carry no spatial connotations.

${ }^{39} \mathrm{KrV}:$ ' $[\ldots]$ weil wir außer unserer Erkenntnis doch nichts haben, welches wir dieser Erkenntnis als korrespondierend gegenübersetzen könnten.'

40 (Collins 1999, ch.5) includes a detailed discussion of the concept of representation in the Critique.

${ }^{41} \mathrm{KrV}$ : 'Es sind demnach die Gegenstände der Erfahrung niemals an sich selbst, sondern nur in der Erfahrung gegeben, und existieren außer derselben gar nicht.'
} 
experience we must encounter such a perception, or it has no meaning at all.' (A493/ B521, my emphasis). ${ }^{42}$ Call this the experiential thesis: all empirical objects lie within the framework of possible experience. ${ }^{43}$

To be situated within the framework of possible experience is to be a potential object of experience: thus for something to be an empirical object, it must be possible for it to be given to a subject in experience. How we are to understand this claim will depend on the notion of possibility involved. Certain passages in the Critique suggest that possible experience is to be understood as no more than past, present and future actual experience. ${ }^{44}$ Others suggest a more expansive notion. ${ }^{45}$ In the discussion of magnetic matter, for example, the notion of possibility extends beyond what is merely physically possible for us given 'the constitution of our organs', for 'the crudeness of [our senses] does not affect the form of possible experience in general' (A226/ B274). ${ }^{46}$ Determining this 'form of possible experience' is an important interpretative project, but it is enough for us to note that Kant never departs from his assertion in the Prolegomena that 'objects which cannot be given in any experience are nothing for us' (4:336) ${ }^{47}$ and that it is this commitment which is expressed by the experiential thesis. ${ }^{48}$

Why does Kant endorse this claim? His reasons can be found in his account of the transcendental ideality of space and time. In the Transcendental Aesthetic, Kant argues that space and time are nothing other than the intuitive conditions of human experience, and since all objects of outer perception are in space and time, it follows that it is only

\footnotetext{
${ }^{42} \mathrm{KrV}$ : 'Vor der Wahrnehmung eine Erscheinung ein wirkliches Ding nennen, bedeutet entweder, daß wir im Fortgange der Erfahrung auf eine solche Wahrnehmung treffen müssen, oder es hat gar keine Bedeutung.'

${ }^{43}$ It is this thesis which partly explains Kant's acceptance of the acquisition version of (EC): empirical concepts must be capable of being derived from experience because it is only in experience that we are presented with empirical objects in such a way that we could use this material for comparison, reflection and abstraction.

${ }^{44}$ E.g., (A493/ B521) - which claims that we must encounter the unperceived object.

${ }^{45}$ See (A492-3/ B521) which claims only that we could encounter such things.

${ }^{46} \mathrm{KrV}:$ ' $[\ldots]$ deren Grobheit die Form möglicher Erfahrung überhaupt nichts angeht.'

${ }^{47}$ Prol: '[...] eben darum weil sie uns in keiner Erfahrung gegeben werden können und also für uns nichts sind.'

${ }^{48}$ Kant's Second Postulate of Empirical Thought is sometimes read as requiring that empirical existence requires only a causal connection with an actually perceived objects (e.g. by Broad (1978, pp.186-7)). But the ensuing discussion of magnetic matter and Kant's general scepticism about the possibility of cognizing determinate causes on the basis of given effects (e.g., at (A368)) suggest that this is best understood as the claim that the actuality of an object is determined by our being related to it through experience. See (Gardner 1999, p.198).
} 
through sensible experience that such objects of perception can be given to us. ${ }^{49}$ More generally if one thinks that an empirical object just is something with a spatio-temporal location, then Kant's claim that space and time are the forms of intuition entails that anything which is an empirical object must be capable of being met with in possible experience. As items with spatio-temporal locations, empirical objects bear a necessary connection to human intuition. The experiential thesis follows from Kant's views about the nature of space and time.

This is spelled out most clearly in Section Six of the Antinomies. ${ }^{50}$ There Kant argues that the empirical reality of the objects of perception is secured because empirical objects are intuited in space and time. But space and time are the pure forms of sensible intuition, which is to say a capacity for being affected in a certain way with representations. It is only those representations which are connected in the relations of space and time according to the laws of the unity of experience which are called objects (A494/ B522). Thus it is the empirical reality of the objects of perception - that is, their reality in space and time - together with the claim that space and time are the forms of sensibility which entails that all empirical objects must be capable of being given in experience. ${ }^{51}$

This connection between empirical objects and possible experience underlies the capacity of objects to exist unperceived. Kant writes:

That there could be inhabitants of the moon, even though no human being has ever perceived them, must of course be admitted; but this means only that in the possible progress of experience we could encounter them... (A492-3/ B521) ${ }^{52}$

\footnotetext{
${ }^{49}$ See (A19-59/ B33-73)

50 (A491-7/ B519-525). See also Prolegomena (4:336-338).

51 This focus on space and time highlights the fact that our concern is with buman intuition specifically. Kant allows that there may be other forms of sensible intuition, but claims that empirically real objects ('extended beings') can only be considered 'from the human standpoint [dem Standpunkte eines Menschen]' (A26/ B42). So any investigation into our ability to think of empirical objects as capable of existing unperceived requires consideration specifically of the role that space and time play in structuring our experience.

$52 \mathrm{KrV}$ : 'Daß es Einwohner im Monde geben könne, ob sie gleich kein Mensch jemals wahrgenommen hat, muß allerdings eingeräumt werden, aber es bedeutet nur so viel: daß wir in dem möglichen Fortschritt der Erfahrung auf sie treffen könnten [...]'. See also (A497-7/ B524-5), and Kant's discussion in 'The Postulates of Empirical Thought', especially the passage at (A225/ B272).
} 
This passage makes explicit the link between an unperceived existent and our possible experience of it: empirical objects only count as existing at a time when they are not perceived because it is possible for a subject to encounter them in future experience. Indeed, given the fact that such notions as endurance and extension only apply within the realm of appearances, the notion of an enduring thing existing beyond our transient experiences of it has to be cashed out in terms of our possible experiences. The capacity of objects to exist unperceived is to be understood in terms of what we can encounter in possible experience. ${ }^{53}$

Such a conditional account of existence unperceived is reminiscent of that famously offered by Berkeley, so it is important to note that in giving such an account, Kant need not be committed to endorsing a phenomenalist reductive account of the reality of unperceived empirical objects. All such a conditional account requires is an essential connection between unperceived existence and possible experience. For Kant, categorical assertions about the possibility of enduring empirical objects which continue to persist through our transient experiences of them are made true by facts about the range of our possible experience. This alone constitutes his endorsement of a conditional account of existence unperceived. It is a further question whether those empirical objects are to be understood as constructions out of private, mental entities. ${ }^{54}$

Kant's account of empirical objects, then, involves an endorsement of the experiential thesis: all empirical objects fall within the framework of possible experience. Something which could not be given in possible experience - something which lay outside the bounds of what it is possible for us to experience - would not count as an empirical object. And it follows from this that the capacity of an empirical object to exist unperceived is constituted by facts about a subject's possible experiences. An empirical object is capable of existing unperceived only if it is possible for us to encounter it in the advance of possible experience. How does this bear on our discussion of (UE)?

We can begin thinking about the implications of this account of empirical objects by considering Kant's notion of objective validity. When discussing

\footnotetext{
${ }^{53}$ Collins and Gardner stress this aspect of Kant's views: (Collins 1999: p.55), (Gardner 1999: p.274).

${ }^{54}$ Compare (Berkeley 1998: §3). Strawson reads Kant's account of empirical objects as 'closer to Berkeley than he [Kant] acknowledged' (Strawson 1966: p.22).
} 
the objective validity of a concept, Kant contrasts it with the possibility of a concept being 'entirely empty' and finding 'no object anywhere amongst the appearances' (A90/ B122). ${ }^{55}$ Empty concepts are ones which have 'the logical form of a concept (of thinking)' but lack the possibility of being related to an object; without such a relation a concept 'has not sense, and is entirely empty of content' (A239/ B298). ${ }^{56}$ This suggests that objectively valid concepts are those which relate to an object, whilst empty concepts are ones which are logically consistent but lack such a relation. ${ }^{57}$

How should we understand this distinction? In a footnote to the B Preface, Kant expands upon the notion of objective validity. In order to ascribe objective validity to a concept, he says, something more than the logical consistency of the concept is required: we also have to know that the concept is 'really possible' - by which he means know that it is possible for objects to fall under the concept (Bxxvi). Objectively valid concepts, on this account, are those for which it can be proved possible for objects to fall under them, whereas empty concepts are those which are logically consistent but lack such a proof. And this explains the significance of the distinction, for Kant holds that knowledge (cognition: Erkenntnis) requires more than the logical consistency of the concepts involved in the knowledge claim; it also requires that we know that it is possible for objects to fall under those concepts.

This is stated most clearly in the footnote to the B Preface. Kant writes:

To cognize an object, it is required that I be able to prove its possibility (whether by the testimony of experience from its actuality or a priori through reason). But I can think whatever I like, as long as I do not contradict myself, i.e., as long as my concept is a possible thought, even if I cannot give assurance whether or not there is a corresponding object somewhere within the sum total of all possibilities. (Bxxvi) ${ }^{58}$

\footnotetext{
${ }^{55} \mathrm{KrV}$ : '[...] ob ein solcher Begriff nicht etwa gar leer sei und überall unter den Erscheinungen keinen Gegenstand antreffe.'

${ }^{56} \mathrm{KrV}$ : '[...] hat er keinen Sinn, und ist völlig leer an Inhalt [...]'.

${ }^{57}$ Although Kant uses the terms 'objective validity' and 'objective reality' in a variety of contexts, I take this usage in his discussion of the objective validity of the categories to capture one central and important meaning of these terms.

${ }^{58} \mathrm{KrV}$ : 'Einen Gegenstand erkennen, dazu wird erfordert, daß ich seine Möglichkeit (es sei nach dem Zeugnis der Erfahrung aus seiner Wirklichkeit, oder a priori durch Vernunft) beweisen könne. Aber denken kann ich, was ich will, wenn ich mir nur nicht selbst widerspreche, d.i. wenn mein Begriff nur ein möglicher Gedanke ist, ob ich zwar dafür nicht stehen kann, ob im Inbegriffe aller Möglichkeiten diesem auch ein Objekt korrespondiere oder nicht.'
} 
We can think what is logically possible through the use of empty concepts, but in order to cognise or know a proposition, we must be able to prove that it is possible for an object to fall under the concepts which compose it. Empty concepts can be used in thought, but only objectively valid concepts feature in knowledge claims. To know a proposition, we must know that its concepts possess real possibility. ${ }^{59}$

Objectively valid concepts, then, are those which relate to an object, and a concept relates to an object just in case it is possible to prove the possibility of objects falling under that concept. The result is what Andrew Chignell has termed a modal condition on knowledge: $S$ knows that $p$ only if $S$ can prove the real, and not merely logical, possibility of the concepts involved in $\mathrm{p}$ (Chignell 2009: p.190). In order to know a proposition I must be able to prove that it is possible for objects to fall under the concepts which compose it. Without such a proof I may believe the proposition, but I lack the epistemic confidence necessary for my belief cannot count as knowledge. Objective validity is necessary for knowledge because it is only objectively valid concepts which we can be sure allow the possibility of objects falling under them.

With this in mind, let us return to our discussion of (UE). Consider the following proposition:

(U): Empirical objects can exist unperceived.

If $(\mathrm{U})$ is capable of being known, then the concepts which compose (U) must be objectively valid. Let $U E$ stand for the conception of objects as capable of existing unperceived, and let us say that the proposition (U) involves the conception $U E$. Then $(\mathrm{U})$ is capable of being known, only if $U E$ is an objectively valid concept. And it will be an objectively valid concept only if it can be proved that it is possible for objects to fall under $U E$.

Can such a possibility be proved? We can find two lines of thought in Kant which would seem to present a challenge to such a proof. The first is that we do not experience objects as existing unperceived. If we do not experience objects existing unperceived, then we cannot adduce our experience of the actuality of objects falling under $U E$ as proof of the

${ }^{59}$ On Kant's distinction between logical and real possibility, see (Chignell 2009). 
possibility of objects falling under $U E$. So a certain sort of empirical proof would seem to be ruled out. ${ }^{60}$ The second thought is that the target for the deployment of $U E$ is empirical objects in general, thus any proof of the possibility of objects falling under $U E$ would have to support the thought that empirical objects in general were capable of falling under $U E$. But any appeal to our experience of the world will necessarily be limited to a subset of that general domain, and thus would seem unable to support the wider conclusion. ${ }^{61}$ If these thoughts can be made good, then there are prima facie obstacles to a proof of the objective validity of $U E$, and a corresponding sceptical challenge to our knowledge of $(U)$.

These obstacles are compounded if one takes the categories to collectively constitute our conception of objects as capable of existing unperceived, for Kant suggests that one cannot adduce experiences for the proof of the objective validity of a priori concepts (A90/ B122). This is important if one is sympathetic to the thought that there is a sense in which the capacity to exist unperceived is given in experience, as suggested above, for this presentation in experience depends for Kant on the presence of schemata which relate the categories to objects. For Kant, any proof of the real possibility of a categorial concept requires a proof of the role of schemata in providing the concept with content, and such a proof cannot be based solely on experience. ${ }^{62}$ The problem highlighted seems intuitive: how could experience tell us that objects were capable of falling under $U E$ ? In the absence of such a proof, the sceptical problem remains.

Kant's response is to provide an alternative proof of the objective validity of $U E$ - and it is here that his account of empirical objects enters the argument. For Kant holds that it can be proved possible for objects to fall under $U E$ only if the capacity of objects to exist unperceived is constituted by facts about a subject's possible experiences. The thought is simple: let the capacity of objects to exist unperceived be understood in terms of a subject's possible experiences. Then for an object to fall under $U E$, all that has to be the case is that it is possible for a subject to experience that empirical object. Since empirical objects must be given in experience, all empirical objects are such that it is possible for a subject to experience them. Thus, all empirical objects are capable of existing unperceived. Because of the link between unperceived existence and possible experience, 
we can prove with full generality that it is possible for objects to fall under $U E$. The two obstacles noted above are sidestepped, and the possibility of objects falling under $U E$ is secured. $U E$ is an objectively valid concept. ${ }^{63}$

We can summarise this argument as follows:

1. A proposition is capable of being known only if it is composed of objectively valid concepts.

2. A concept is objectively valid if and only if it can be proved that it is possible for objects to fall under it.

3. The proposition $(\mathrm{U})$ involves the conception $U E$.

4. (U) is capable of being known only if $U E$ is an objectively valid concept.

5. $U E$ is objectively valid only if it can be proved that it is possible for objects to fall under $U E$.

6. It can be proved that it is possible for objects to fall under $U E$ only if the capacity of objects to exist unperceived is constituted by facts about a subject's possible experiences.

7. Thus, if $(\mathrm{U})$ is capable of being known, the capacity of objects to exist unperceived must be constituted by facts about a subject's possible experiences.

Claims (1) and (2) state Kant's views on the relation between logical possibility, real possibility and knowledge, whilst claim (6) is supported by Kant's understanding of what is required to ensure the generality of a suitable proof. The result is a line of thought extractable from Kant's discussion of empirical objects which ties our cognition of (U) to a particular account of the nature of unperceived existence.

How does this bear on our discussion of (UE)? According to (UE), experience explains our conception of objects as capable of existing unperceived. Can this discussion be used to support a Kantian account of experience's explanatory role?

Let us begin with that which needs explanation. On the Kantian model, we can know that empirical objects are capable of unperceived existence only if our conception of objects as capable of unperceived existence

${ }^{63}$ For other passages relevant to this argument, see (A155/ B194), (A244), (A147/ B187), (A246/ B303). 
possesses objective validity. In order to secure such knowledge against sceptical challenge, then, we must provide an account of how it is that this conception gains objective validity. This issue is pressing because those concepts which lack objective validity are incapable of featuring in cognitive judgements (A239/ B298; A244; A147/ B187). Thus if our conception of objects is to have the kind of significance required to play a cognitive role in epistemic claims, we need to provide an explanation of our conception of objects as capable of existing unperceived: we need to explain its objective validity.

What kind of explanation can be provided? According to the Kantian argument outlined above, the objective validity of this conception is explained by the constitutive relation which holds between the capacity of objects to exist unperceived and facts about a subject's possible experiences. Since the capacity of objects to exist unperceived bears a constitutive link to the framework of possible experience, we can prove with full generality that our conception of unperceived existence relates to empirical objects. The explanation of the objective validity of this conception of objects thus rests on the connection between unperceived existence and possible experience: it is because all empirical objects lie within the framework of possible experience that we can think of them as capable of existing unperceived.

Does this explanation accord the experience of empirical objects an explanatory role? In characterising experience as playing an explanatory role, the aim is to capture the thought that certain ways of thinking about the world require a connection to experience. ${ }^{64}$ One who denied (UE) might hold that our ways of thinking about objects as capable of existing unperceived require no such connection: certain sense-datum theories of experience, for example, take the continued existence of empirical objects to be a theoretical posit postulated to explain patterns of senseimpressions. ${ }^{65}$ On such models, we do not need to experience empirical objects in order to think about them as capable of existing unperceived: experience plays no explanatory role.

The Kantian account I have offered stands in opposition to this claim. Our capacity to think about empirical objects as capable of existing unperceived

\footnotetext{
${ }^{64}$ See the references in $n .2$ above.

${ }^{65}$ E.g. (Ayer 1973)
} 
requires a basic and fundamental connection to experience: it is only because empirical objects are the kinds of things which we can and do come across in the advance of possible experience that our conception of them as existing unperceived has the character that it does. We can think about such objects as enduring independently of our perceptions only because they fall within the framework of a subject's possible experiences. Such an explanation abjures any attempt to explain our conception of objects by appeal to the method by which that conception was acquired. Instead it offers an explanation of how our conception of objects as capable of existing unperceived possesses the kind of content required to feature in knowledge-claims about the world.

This, then, is a Kantian account of experience's explanatory role, one which relies on the fact that the capacity to exist unperceived is constituted by facts about one's possible experiences. On this account, the experience of empirical objects is explanatorily basic because any account of our conception of objects as capable of existing unperceived must advert to a link between the capacity of objects to exist unperceived and a subject's possible experience of objects: to this extent, it must situate the possible experience of empirical objects at its base. It is the possible experience of empirical objects which grounds our explanation of how our conception of unperceived existents relates to the world.

\section{Transcendental Idealism}

Our starting point was the observation that we possess various ways of thinking about the world as capable of existing independently of us and of the objects which populate it as embodying such 'rigid fidelity'. These ways of thinking about the world are evinced in the judgements we make using the concepts of ordinary physical objects: when we think of the cup left in the kitchen as enduring in our absence, we are operating with a conception of objects as capable of existing unperceived. I have suggested that there is a Kantian line of support for the claim that this way of thinking about objects is explained by our experience of the world, not because that way of thinking involves a conception of objects which is derived from experience, but because such a conception requires a connection to experience in order to possess the kind of objective significance necessary for epistemic status. 
How plausible is this account of experience's explanatory role? Central to this Kantian defence is a link between unperceived existence and possible experience, a link which is supported by the claim that empirical objects are all situated within the framework of possible experience. I termed this Kant's experiential thesis. Endorsing this account of experience's explanatory role requires us to defend the experiential thesis. What grounds do we have for accepting this claim?

As I have tried to draw out, Kant's reason for thinking that unperceived existents must be met with in possible experience is that he takes space and time to be transcendentally ideal: it is because space and time are the pure forms of human intuition that empirical objects must be given in experience. For empirical objects are objects that are situated in space and time, and since space and time are nothing more than the forms of human intuition, empirical objects can only be given in intuition. Taking transcendental idealism to be the doctrine that that all appearances are 'to be regarded as mere representations and not things in themselves, and accordingly that space and time are only sensible forms of our intuition' (A369) ${ }^{66}$ this means that Kant's defence of the experiential thesis relies upon his transcendental idealism. Given the standard regard for transcendental idealism, this would appear to be an unfortunate result.

Can the experiential thesis be defended outside of the Kantian framework? There may be some reason to demur. Consider elusive objects, defined by Timothy Williamson as objects that are in principle incapable of being individually the subject of thoughts, or the Enigmas, Mark Johnston's class of entities that are essentially undetectable by us. ${ }^{67}$ In the absence of a commitment to transcendental idealism, can we rule out the possibility of such objects? Unless we can provide a guarantee that the class of empirical objects does not include elusive objects or enigmas, then we must reject the claim that all empirical objects are capable of being given in experience. But this is to break the link between empirical objects and possible experience, and thus to disavow the Kantian defence of (UE). Without a

\footnotetext{
${ }^{66} \mathrm{KrV}$ : 'Ich verstehe aber unter dem transzendentalen Idealism aller Erscheinungen den Lehrbegriff, nach welchem wir sie insgesamt als bloße Vorstellungen, und nicht als Dinge an sich selbst, ansehen, und demgemäß Zeit und Raum nur sinnliche Formen unserer Anschauung $[\ldots]$ '. 67 (Williamson 2006, p.110), (Johnston 1993, pp.96-7)
} 
defence of the experiential thesis, Kant's account of experience's explanatory role cannot proceed. ${ }^{68}$

I suggest, then, that there is material in the first Critique which can be used to provide an account of why experience explains our understanding of objects as capable of existing unperceived; one which focuses on the connections necessary for our thinking about objects to be objectively valid. But this defence relies upon Kant's claims about the nature of space and time, claims which are far from beyond dispute. And, in a way, this should come as no surprise, for Kant repeatedly stresses that his transcendental idealism and empirical realism are closely linked. ${ }^{69}$ It is the transcendental idealist who is an empirical realist, and grants to matter, as appearance, a reality which need not be inferred but is immediately perceived (A371). Empirical realism, for Kant, entails transcendental idealism, and it is the binding of these two theses which - I have suggested - allows a Kantian defence of experience's explanatory role. If there is material in the first Critique which can be used to provide an account of the explanatory role of experience, it is material which cannot be separated from Kant's wider transcendental framework. ${ }^{70}$

\section{References}

Allison, H. 1983 Kant's Transcendental Idealism. New Haven: Yale University Press

Anscombe, G.E.M. 1981 'Causality and Determination', in her Metaphysics and the Philosophy of Mind: Collected Papers. Oxford: Blackwell

Ayer, A.J. 1973 The Central Questions of Philosophy. London: Weidenfeld

\footnotetext{
${ }^{68}$ Certain scientific objects may make this point equally well. Given a suitably expansive reading of possible experience, it may be possible for magnetic matter or electrons to be given to us in experience, but the same cannot be said of all scientific objects. It is simply not clear what it would be for single quarks or dark matter to be given in experience. Thanks to Babiker Hassanain for advice.

${ }^{69}$ For example, at (A27-28/ B44), (A35-6/ B52) and later at (A42-3/ B59-60).

70 Ancestors of this paper were presented at seminars in Birkbeck and King's Colleges, London, and at the 'Transcendental Philosophy: Its History and Nature' conference in Manchester in April 2009. My thanks to all the participants for their questions and comments, especially Lucy Allais, John Callanan, Rory Madden, Christian Onof, Joel Smith and Bob Stern. Thanks also to Babiker Hassanain, Adrian Moore, Andrew Stephenson and three anonymous reviewers for their comments and advice.
} 
Bennett, J. 1966 Kant's Analytic. Cambridge: Cambridge University Press

Berkeley, G. 1998 A Treatise Concerning the Principles of Human Knowledge, ed. J. Dancy. Oxford: Oxford University Press

Broad, C.D. 1978 Kant: An Introduction. Cambridge: Cambridge University Press

Campbell, J. 2002a 'Berkeley's Puzzle', in T.Gendler and J.Hawthorne (eds) Conceivability and Possibility. Oxford: Oxford University Press

Campbell, J. 2002b Reference and Consciousness. Oxford: Clarendon Press

Campbell, J. 2006 'Manipulating Colours: Pounding an Almond', in T. Gendler and J. Hawthorne (eds.), Perceptual Experience. New York: Oxford University Press

Cassam, Q. 2003 'A Priori Concepts', in H. Glock (ed.) Strawson and Kant. Oxford: Oxford University Press

Chignell, A. 2009 'Kant, Modality, and the Most Real Being', Archiv für Geschichte der Philosophie 91: 157-192

Child, T.W. 1994 Causality, Interpretation and the Mind. Oxford: Clarendon Press

Collins, A.W. 1999 Possible Experience. Los Angeles: University of California Press

Evans, G. 1980 'Things without the Mind: A Commentary upon Chapter Two of Strawson's Individuals', in Z. Van Straaten (ed.) Philosophical Subjects: Essays Presented to PF. Strawson. Oxford: Clarendon Press

Evans, G. 1982 The Varieties of Reference. Oxford: Clarendon Press

Gomes, A. 2011 'Is Kant's Transcendental Deduction of the Categories Fit for Purpose?', Kantian Review 15 (2):118-137

Johnston, M. 1993 'Objectivity refigured: pragmatism without verificationism' in J. Haldane and C. Wright (eds.) Reality, Representation and Projection. Oxford: Oxford University Press

Kant, I. 1973 On a Discovery tr. H. Allison. London: John Hopkins University Press

Kant, I. 1977 Proleomena to Any Future Metaphysics, tr. P. Carus, rev. J.

Ellington. Indianapolis: Hackett Publishing Company

Kant, I. 1987 Critique of Judgement, tr. W.S. Pluhar. Indianapolis: Hackett Publishing Company

Kant, I. 1992 Lectures on Logic, tr. J. Michael Young. Cambridge: Cambridge University Press

Kant, I. 1998 Critique of Pure Reason, tr. P. Guyer and A. Wood. Cambridge: Cambridge University Press

Kant, I. 2006 Anthropology from a Pragmatic Point of View, tr. R.B. Louden. Cambridge: Cambridge University Press

Longuenesse, B. 1998 Kant and the Capacity to Judge. Princeton: Princeton University Press

Longuenesse, B. 2005 'Kant's Categories', in her Kant and the Human Standpoint. Cambridge: Cambridge University Press 
Margolis, E. and Laurence, S. 'Concepts', The Stanford Encyclopedia of Philosophy (Fall 2008 Edition), E. Zalta (ed.), URL = <http://plato.stanford.edu/archives/fall2008/entries/concepts/>.

Martin, M.GF. 2002 'Particular Thoughts and Singular Thoughts', in A. O'Hear (ed.) Logic, Thought and Language. Cambridge: Cambridge University Press

Matthews, H.E. 1982 'Strawson on Transcendental Idealism' in R.C.S. Walker (ed.) Kant on Pure Reason. Oxford: Oxford University Press

McDowell, J. 1986 'Singular Thought and the Extent of Inner Space'. Reprinted in his 1998 Meaning, Knowledge and Reality. Cambridge MA: Harvard University Press: 228-59.

Strawson, P.F. 1966 The Bounds of Sense. London: Methuen

Williamson, T. 2006 'Past the Linguistic Turn?', in B. Leiter (ed.) The Future for Philosophy. Oxford: Oxford University Press 